\title{
Up-Regulation of Fetal Rat Lung Parathyroid Hormone-Related Protein Gene Regulatory Network Down-Regulates the Sonic Hedgehog/Wnt/ßcatenin Gene Regulatory Network
}

\author{
JOHN S. TORDAY AND VIRENDER K. REHAN \\ Department of Pediatrics [J.S.T., V.K.R.], Department of Obstetrics and Gynecology [J.S.T.], Los Angeles Biomedical Research Institute at \\ Harbor-UCLA, Torrance, California, 90502
}

\begin{abstract}
Lung development depends on endodermal Sonic Hedgehog (Shh) signaling to mesodermal Wingless/int/beta catenin (Wnt/ßcatenin), followed by parathyroid hormone-related protein (PTHrP) signaling from endoderm to mesoderm. Fluid distension of fetal rat lung explants up-regulates PTHrP signaling and downregulates $\mathrm{Shh} / \mathrm{Wnt} / \beta$ catenin signaling, marked by decreases in Patched, Gli, Frizzled, and Dishevelled, inducing fibroblast triglyceride uptake, type II cell saturated phosphatidylcholine, and surfactant protein-B expression. Bumetanide, which inhibits fluid distension, blocked down-regulation of the $\mathrm{Shh} / \mathrm{Wnt} / \beta$ catenin pathway and up-regulation of the PTHrP pathway, whereas PTHrP $(1-34,5 \times$ $\left.10^{-7} \mathrm{M}\right)$ treatment overcame bumetanide inhibition, and the PTHrP receptor antagonist PTHrP $(7-34)$ amide $\left(5 \times 10^{-6} \mathrm{M}\right)$ mimicked bumetanide, indicating that PTHrP signaling mediates fluid distension-induced alveolar differentiation. Fetal rat lung explant automaturation was characterized by decreased $\mathrm{Wnt} / \beta$ catenin signaling and increased PTHrP/PTHrP receptor signaling, up-regulating fibroblastspecific adipocyte differentiation related protein (ADRP) and peroxisome proliferator-activated receptor gamma. Wnt/ $\beta$ catenin agonists ( $\mathrm{LiCl}$ or SB415268) maintained $\mathrm{Shh} / \mathrm{Wnt} / \beta$ catenin signaling, blocking spontaneous up-regulation of the PTHrP pathway, whereas PTHrP or cAMP down-regulated Shh/Wnt/ $\beta$ catenin signaling and stimulated PTHrP signaling for fibroblast and type II cell differentiation. This is the first evidence that alveolar fluid distension is an organizing principle for PTHrP signaling down-regulation of the Shh/Wnt/ $\beta$ catenin pathway. (Pediatr Res 60: 382-388, 2006)
\end{abstract}

$\mathrm{L}$ ung development is characterized by sequential endodermal Shh signaling to the mesodermal $\mathrm{Wnt} / \beta$ catenin pathway (1), followed by PTHrP endodermal-to-mesodermal signaling that culminates in mature AIF and type II cells (2-4). The formation of the alveolar bed during the canalicular and saccular phases of lung development is determined by genetic and epigenetic GRN (5). The plasticity of the alveolar interstitium derives from both the fibroblasts, which are not terminally differentiated (6), and the epithelial cells, which

Received January 11, 2006; accepted June 7, 2006

Correspondence: John S. Torday, Ph.D., Department of Pediatrics and Obstetrics and Gynecology, The Henry L. Guenther Laboratory for Cell/Molecular Research, 1124 W. Carson St., Harbor-UCLA Medical Center, Torrance, CA 90502; e-mail: jtorday@labiomed.org

This study was supported by grants from the National Heart, Lung and Blood Institute (HL55268 and HL075405), the March of Dimes Foundation, and the American Heart Association.

DOI: 10.1203/01.pdr.0000238326.42590.03 differentiate into type II cells (7) and can differentiate into type-I cells (8). These phenotypes are affected by various extrinsic factors, including stretch (9), endocrine hormones $(10,11)$, cytokines (3), oxygen $(12,13)$, nutrition $(14)$, nicotine (15), and inflammation (16).

PTHrP is a stretch-regulated paracrine factor expressed by type II cells that is necessary for the formation of alveoli (17). It signals neighboring mesodermal fibroblasts to differentiate by stimulating cAMP (18). The cAMP-dependent PKA pathway stimulates AIF differentiation by up-regulating PPAR $\gamma$ (15) and the expression of the downstream phenotypic genes for fibroblast and type II cell differentiation. Decreased PTHrP signaling that occurs due to prematurity (19), lung injury $(15,20)$, maternal smoking (21), or infection (S. Dargan-Batra et al., American Thoracic Society, May 20-25, San Diego, CA) can lead to myofibroblast transdifferentiation $(20,22)$. AIF phenotypes are critical for alveolarization (20). Proliferation of alveolar myofibroblasts can lead to either the formation of alveolar septa (22) or to granulomatous scar tissue (23), depending on the cellular environment (20).

We wanted to test the paracrine interaction between the $\mathrm{Shh} / \mathrm{Wnt} / \beta$ catenin and PTHrP signaling pathways in an intact model of lung cell development that would mature without extrinsic factors, under the influence of fluid distension generated actively by the lung, not passively and nonphysiologically by ligation, which does not faithfully reproduce the "normal" lung phenotype (24). Therefore, we used bumetanide, a chloride channel blocker that inhibits lung fluid formation (25) to test this hypothesis in explant culture.

To determine whether PTHrP GRN up-regulation is necessary for down-regulation of the $\mathrm{Wnt} / \beta$ catenin GRN, we chose to study automaturing fetal lung explants in serum- and hormone-free culture (26), as depicted schematically in Figure 1 by steps $1-14$.

\footnotetext{
Abbreviations: AIF, alveolar interstitial fibroblasts; Gli, Glioblastoma; GRN, gene regulatory networks; PKA, protein kinase A; PPAR $\gamma$, peroxisome proliferator-activated receptor gamma; Ptc, Patched; PTHrP, parathyroid hormone-related protein; Shh, Sonic Hedgehog; SP-B, surfactant protein-B; Wnt/ $\boldsymbol{\beta}$ catenin, Wingless/int/beta catenin
} 


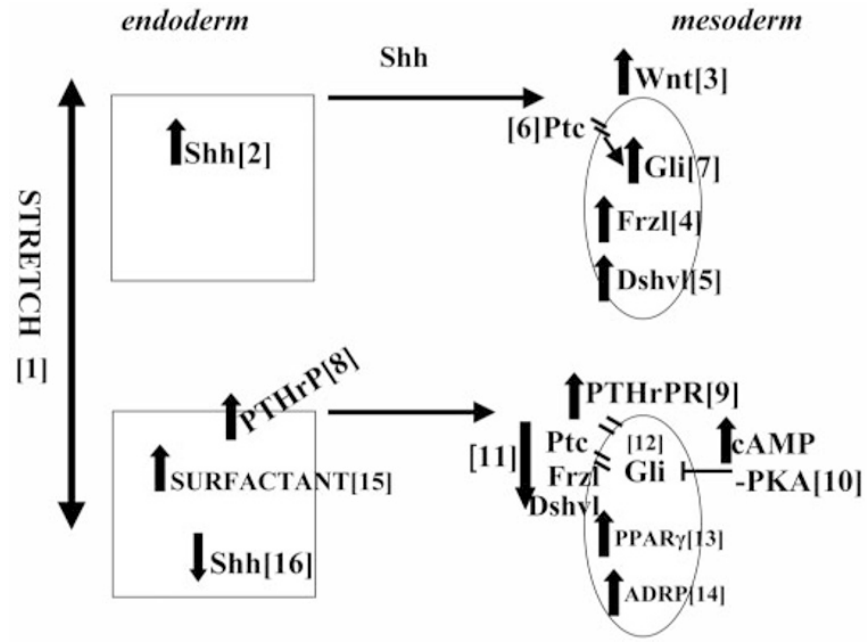

Figure 1. Schematic for automaturation of the alveolar acinus (with references to literature citations). During early embryonic lung development (upper panel) endodermal Shh (2) signals to the mesodermal Wnt/Ptc/Gli pathway (3-7). Maturation of the interstitium is driven by alveolar fluid distension (1), which up-regulates the PTHrP signaling pathway between the endoderm and mesoderm (8-16), down-regulating the Wnt pathway by inhibiting Gli (12) and up-regulating PPAR $\gamma(13)$ and ADRP (14). Differentiation of the lipofibroblast stimulates differentiation of alveolar type II cell surfactant synthesis (15) and inhibition of Shh (16) expression.

\section{MATERIALS AND METHODS}

Animals. Time-mated Sprague-Dawley rats $(\mathrm{e} 0=$ day of mating) were obtained from Charles River Breeders (Holister, CA). The experiments described were conducted in accordance with the National Institutes of Health Guide for the Care and Use of Laboratory Animals and approved by the Los Angeles Biomedical Research Institute Animal Care Committee.

Reagents. Rp-cAMPS, a specific PKA inhibitor, SB-415286, a sensitive and specific GSK $3 \beta$ inhibitor (which stimulates the $\mathrm{Wnt} / \beta$ catenin pathway), lithium chloride, and 8-bromo-cAMP were purchased from Sigma Chemical Co. (St. Louis, MO).

Explant culture. Lung tissue was cultured as previously described (27). Explants derived from three to five litters of rats were used for each experiment during the course of these studies.

Competitive RT-PCR. Total cellular RNA was isolated as previously described (15). The appropriate cDNA fragments were amplified using $400 \mathrm{ng}$ of total RNA from lung explants, avian myeloblastosis virus reverse transcriptase, and random hexamers and deoxyribonucleotides. The following primers and conditions have previously been used in our laboratory for the RT-PCR assays (3,4,9,15): PTHrP (sense, 5'TGGACACCAGCATCTACGTCAG; antisense, 3'GACATGGAGTATCCCACGGTGT); PTHrP receptor (sense, 5'CCTCTTTGGCGTCCACTACATTG; antisense, 3'TTGAGGAACCCATCGTCCTTG; ADRP (sense, 5'ACAGCTCACTTATGGTCGTGCC; antisense, 3'AAACAGTGATGAAGCCTGCTCG); SP-B, (sense, 5'TACACAGTACTTCTACTAGATG; antisense, 3'ATAGGCTGTTCACTGGTGTTCC); PPAR((sense, 5'ATGCTTTATCCCCACAGACTC; antisense, 3'GTTGACACAGAGATGCCATTC. The following primers and conditions were used for the indicated RNA determinations: Shh (sense, 5'CACAAGAAACTCCGAACGATT; antisense, 3'ATGCGAGCTTTGGATTCATAG); Ptc (sense, 5' AAACAGGCATAGGCAAGCATC; antisense, 3'TTGGCAGGAGGAGTTGATTGT); Gli (sense, 5'GACTTCCGACAGCCTTCAAAC; antisense, 3'GGACATGTCTAGCCCCAACTC); Frizzled 1 (sense, 5'CAGTTCACTTCCGACAAAGG; antisense, 5'AGGTAGGAAGGCACCCTGAG); Frizzled 3 (sense, 5' TTTTCCATGGGCGTAGGA; antisense, 5'TAACACGGTTCATGCTGGTG); Frizzled 4 (sense, 5' ACAACCACATGTGCATGGAA; antisense, 5'TCCTTAGCTGAGCGGCTGTA); Frizzled 5 (sense, 5'GACGCCGAGGTTCTGTGTAT; antisense, 5'TGCGCACCTTGTTGTAGAGT); Frizzled 6 (sense, 5'CCCTCGTAAGAGGACACAGC; antisense, 5'TTGCAAGATGCAGAAAGTGC); Disheveled 1 (sense, 5'GGGGGTAGTGGCAGTGAA; antisense, 5'ACCTGTAAGTTCTGGAGGGACA); Dishevelled 2 (sense, 5'GCAGTGGCAGTGAGTCAGAA; antisense, 5'TCATGGGGTTATAGGGGAGAG); Dishevelled 3 (sense, 5'CAAGGAGAAGGACCCAAAAG; antisense, 5'ATCGGGGGACCATAGAGAG); 18s (sense, 5'TTAAGCCATGCATGTCTAAGTAC; antisense,
3'TGTTATTTTTCGTCACTACCTCC). cDNA was synthesized from $1 \mu \mathrm{g}$ total RNA by RT using 100 U Superscript reverse transcriptase II (Invitrogen, Carlsbad, CA) and random primers (Invitrogen) in a $20 \mu \mathrm{L}$ reaction containing $1 \times$ Superscript buffer (Invitrogen), $1 \mathrm{mM}$ deoxy-NTP mix, $10 \mathrm{mM}$ DTT, and $40 \mathrm{U}$ ribonuclease inhibitor. Total RNA and random primers were incubated at $65^{\circ} \mathrm{C}$ for $5 \mathrm{~min}$ followed by $42^{\circ} \mathrm{C}$ for $50 \mathrm{~min}$. A denaturing enzyme at $70^{\circ} \mathrm{C}$ for 15 min terminated the reaction. For PCR amplification, $1 \mu \mathrm{L}$ cDNA was added to $25 \mu \mathrm{L}$ of a reaction mix containing $0.2 \mu \mathrm{M}$ of each primer, $0.2 \mathrm{mM}$ deoxy-NTP mix, 0.5U AccuPrime Taq DNA Polymerase (Invitrogen), and $1 \times$ reaction buffer. PCR was performed in a RoboCycler (Stratagene, La Jolla, CA). The PCR temperature between $50^{\circ}$ and $58^{\circ} \mathrm{C}$ and cycle number between 27 and 38 were selected for optimal absorbance OD for each individual marker studied. The PCR products were visualized on $2 \%$ agarose gels by ethidium bromide staining, and gels were photographed under UV lights. Bands densities were quantified using the Eagle Eye II System (Stratagene). The mRNA levels were normalized to $18 \mathrm{~s}$ mRNA levels.

Triolein uptake assay. Triolein uptake assay was performed as previously described (14).

Choline incorporation assay. Choline incorporation assay was performed as previously described (2).

Statistical analyses. Experiments were repeated three or more times to confirm the validity of observations. The significance of differences within groups was determined by one-way ANOVA with Newman-Keuls posthoc test. Statistical analyses of the relative levels of specific mRNA were performed after arc sine transformation of the ratio data. The null hypothesis was rejected when $p<0.05$ was obtained.

\section{RESULTS}

Effects of inhibitors of fluid distension or Wnt signaling on PTHrP-mediated fetal rat lung explant automaturation. We cultured e14 fetal rat lung tissue in explant culture for up to $5 \mathrm{~d}$ to determine whether fluid distension induced the fibroblast lipogenic phenotype, characterized by triglyceride uptake. Triglyceride uptake increased more after $5 \mathrm{~d}$ in culture (Fig. 2), a lipofibroblast-specific mechanism mediated by PTHrP up-regulation of ADRP. This effect was blocked by incubation of the explants with bumetanide $\left(2 \times 10^{-4} \mathrm{M}\right)$, an inhibitor of fluid secretion by fetal lung explants. To determine whether PTHrP mediated this effect, we co-incubated the explants with bumetanide and PTHrP $\left(5 \times 10^{-5} \mathrm{M}, 5 \times 10^{-7}\right.$

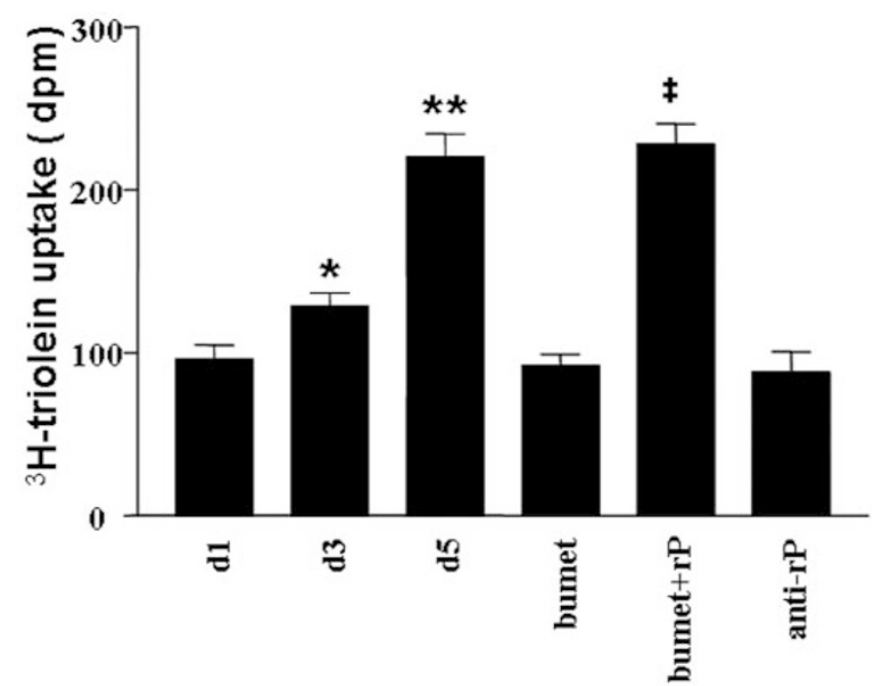

Figure 2. Fluid distension causes PTHrP-mediated lung maturation in vitro. Fetal rat lung explants were treated with bumetanide (bumet, $2 \times 10^{-4} \mathrm{M}$ ), $\operatorname{PTHrP}\left(r P, 5 \times 10^{-7} \mathrm{M}\right)$, PTHrP (7-34) amide (anti-rP, $\left.5 \times 10^{-6} \mathrm{M}\right)$, as indicated, from d 0 to 5 in culture. On d 1, 3, and 5 , the explants were incubated with ${ }^{3} \mathrm{H}$-triolein. Each bar represents the mean $\pm \mathrm{SD}, n=5$. * $p<$ $0.05, * * p<0.01$, d 3, d $5 v s \mathrm{~d} 1 ; \ddagger p<0.0001$, bumet $v s$ bumet $+\mathrm{rP}$, by one-way ANOVA. 
$\mathrm{M}$, respectively), and found that PTHrP restored the bumetanide-inhibition of triglyceride uptake; incubation of the explants with the specific PTHrP receptor antagonist PTHrP (7-34) amide $\left(5 \times 10^{-6} \mathrm{M}\right)$ blocked the increase in triglyceride uptake, verifying that endogenous PTHrP mediated the increase in triglyceride uptake by the maturing explants. Bumetanide did not affect basal triglyceride uptake, or PTHrP and PTHrP receptor mRNA levels, indicating that it specifically blocked fluid distension without affecting PTHrP signaling itself. Incubation of the explants with the GSK-3 $\beta$ inhibitor SB415286 $\left(5 \times 10^{-7} \mathrm{M}\right)$, a Wnt pathway agonist, also blocked the spontaneous increase in triglyceride uptake, an effect overridden by co-incubation with PTHrP (1-34) $(5 \times$ $10^{-7} \mathrm{M}$ ), suggesting that PTHrP stimulates fibroblast differentiation by down-regulating the Wnt pathway. To test this hypothetical mechanism we performed the following series of experiments.

Effect of Wht inhibitors on fibroblast and type II cell maturation in PTHrP-dependent automaturing fetal rat lung explant cultures. First, we determined the mRNA levels of Wnt signaling genes during automaturation of the fetal rat lung cultures. As can be seen in the left panel of Figure 3, Frizzled 1, 3, 4, and 5 mRNA levels markedly decreased (50, $86,37,76 \%$, respectively) between e14 and e19, whereas Frizzled 6 increased by $44 \%$ during this same period; and, as can be seen in the right panel of Figure 3, Disheveled 2 and 3 mRNA levels decreased by 30 and 35\%, respectively, whereas Disheveled 1 increased 109\%. We then examined the mRNA levels of PTHrP and its signaling genes for fibroblast maturation, namely the PTHrP receptor, ADRP, and PPAR $\gamma$, during the process of lung maturation in vitro (Fig. 4). We observed a progressive increase in the expression of PTHrP during the 5-d culture period paralleled by concomitant increases in the expression of the PTHrP receptor, ADRP, and PPAR $\gamma$. We then probed for the expression of SP-B and Shh as functional markers for type II cell differentiation and probed for the fibroblast Shh/Wnt pathway-regulated genes, Gli and Ptc. There was a progressive increase in SP-B expression over the 5-d incubation period (Fig. 5), indicative of type
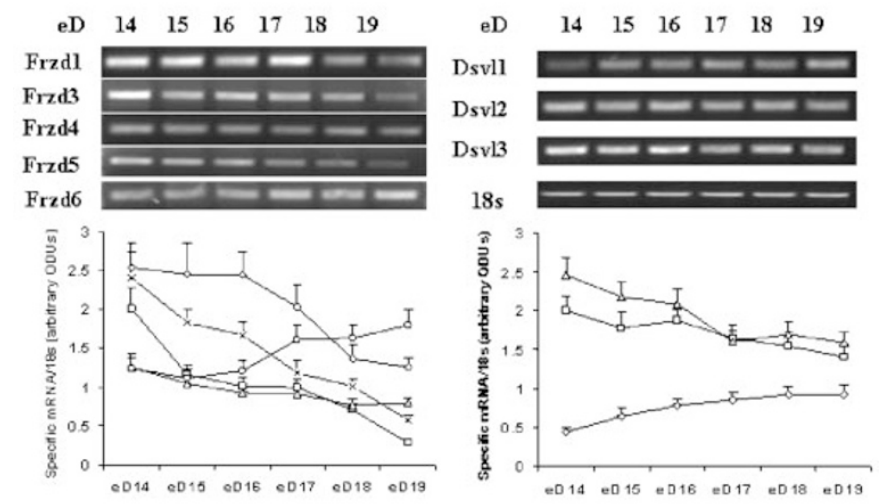

Figure 3. Fetal rat lung explant automaturation down-regulates Wnt pathway signaling. Fetal rat lung explants were cultured for up to $5 \mathrm{~d}$ and were harvested daily from d 0 to 5, equal to e14-19 ex vivo. RT-PCR of Frizzled and Dishevelled was used to monitor the pattern of Wnt signaling. Frizzled 1 $\left.(-\rangle_{-}\right), 3(-\square-), 4\left(-\triangle_{-}\right), 5(-\times-), 6(-\bigcirc-)$; Disheveled $1\left(-\diamond_{-}\right), 2(-\square-)$, $3(-\triangle-)$. Values are means $\pm \mathrm{SD}, n=5$.

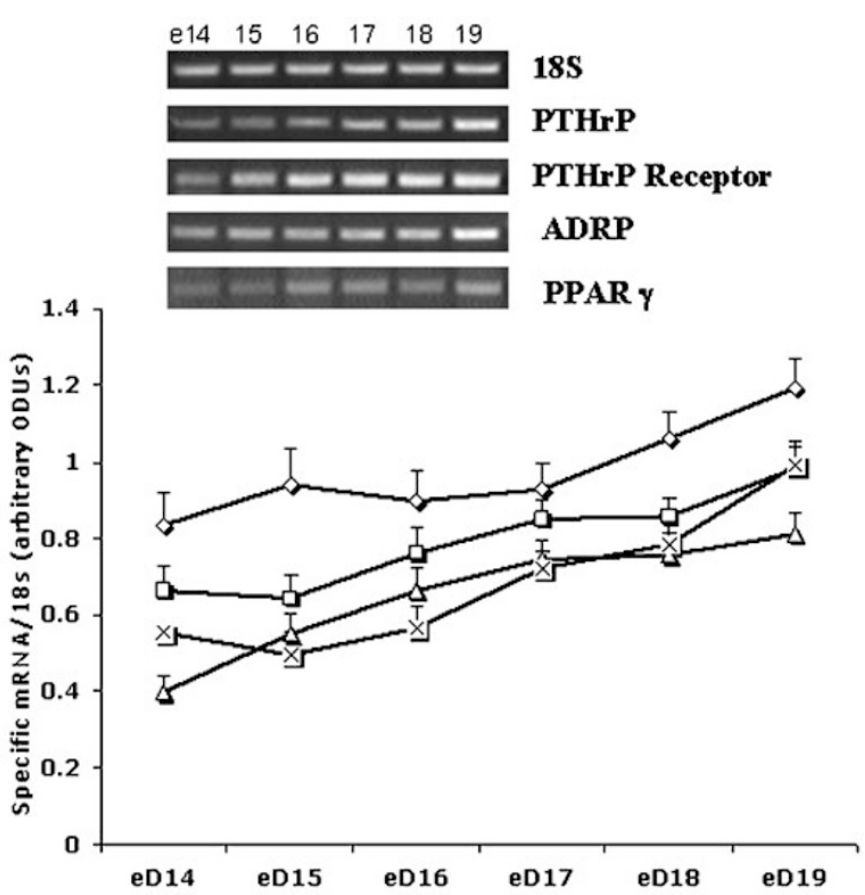

Figure 4. Fetal rat lung explant automaturation coordinately up-regulates PTHrP signaling between type II cells and fibroblasts. Fetal rat lung explants were cultured for up to $5 \mathrm{~d}$ and were harvested daily from $\mathrm{d} 0$ to 5 , equal to e14-19 ex vivo. RT-PCR of PTHrP expression was used to monitor type II cell differentiation; RT-PCR of PTHrP receptor, ADRP, and PPAR $\gamma$ was used to monitor maturation of PTHrP signaling to fibroblasts. Note the patterns of coordinate up-regulation of PTHrP $\left(-X_{-}\right)$in type II cells with up-regulation of PTHrP receptor $\left(-\triangle_{-}\right)$, ADRP $\left(-\diamond_{-}\right)$, and PPAR $\gamma(-\square-)$ in fibroblasts (see graph below representative gel). Values are means $\pm \mathrm{SD}, n=5$.

II cell maturation, and a concomitant, progressive decrease in the expression of Shh, Ptc, and Gli.

We subsequently determined the effects of $\mathrm{LiCl}$ and SB415286, which stimulate the Wnt pathway by inhibiting GSK-3 $\beta$, on the expression of Shh, which regulates the Shh pathway intermediates Gli and Ptc (Fig. 6). Note the dosedependent effect of graded amounts of $\mathrm{LiCl}(2$ and $5 \mathrm{mM})$ and SB415286 $(10,20$, and $50 \mu \mathrm{M})$, on the incremental increases in Shh, Gli, and Ptc. Treatment of the lung explants with 8-bromo-cAMP $\left(5 \times 10^{-5} \mathrm{M}\right)$, a PTHrP/PKA pathway agonist, completely inhibited the expression of these Shh pathway-regulatory genes.

We then determined the effects of the Wnt and PKA pathways on fibroblast functional differentiation based on triglyceride uptake as an end-point (Fig. 7). cAMP treatment of d 3 explants $\left(10^{-5} \mathrm{M} / 24 \mathrm{~h}\right)$ stimulated triglyceride uptake by $25 \%$; conversely, the GSK-3 $\beta$ inhibitor $\mathrm{LiCl}$ inhibited triglyceride uptake in a dose-dependent manner at 2 and $5 \mathrm{mM}$, inhibiting triglyceride uptake by 20 and $35 \%$, respectively. The PKA agonist cAMP "normalized" the $\mathrm{LiCl}$ effect on triglyceride uptake.

To test the hypothesized role of the PTHrP cAMPdependent PKA pathway in the down-regulation of the Wnt pathway, we treated d 3 fetal rat lung explants with PTHrP or 8-bromo-cAMP for $24 \mathrm{~h}$ in culture and determined their effects on the expression of epithelial SP-B and Shh, and fibroblast Gli and Ptc (Fig. 8). Both PTHrP and cAMP up- 


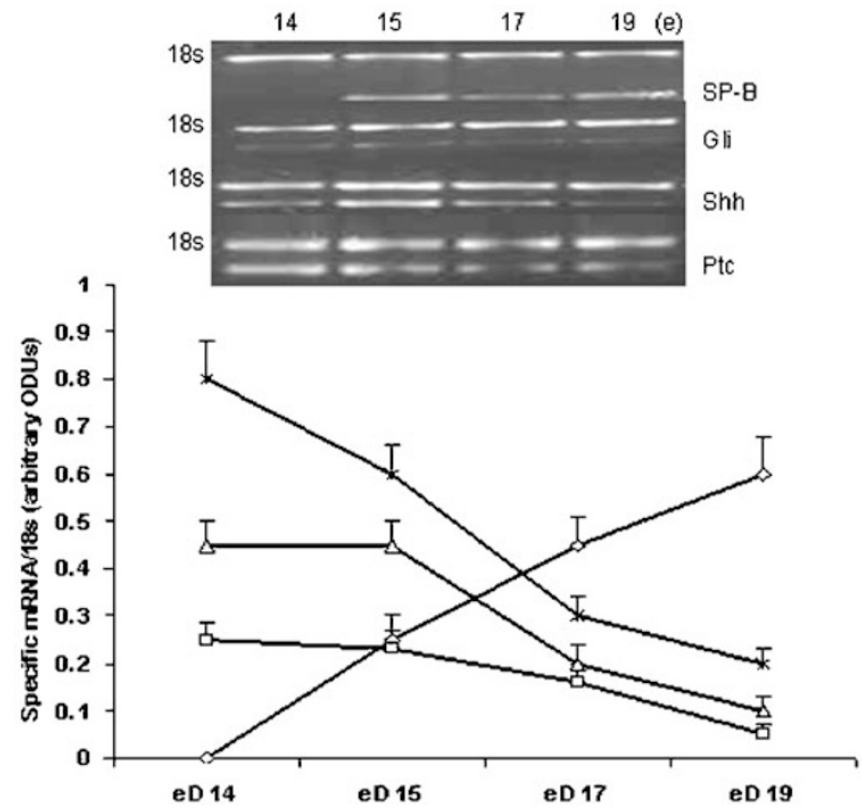

Figure 5. Fetal rat lung explant automaturation coordinately up-regulates maturation of type II cells and down-regulates Shh signaling by fibroblasts. Fetal rat lung explants were cultured for up to $5 \mathrm{~d}$, and were harvested 0,1 , 3 , and $5 \mathrm{~d}$ postculture (equal to e15, 17, and 19 ex vivo). SP-B and Shh expression by RT-PCR were used to monitor type II cell differentiation; Gli and Ptc were monitored by RT-PCR for changes in fibroblast Wnt signaling. Note the patterns of spontaneous down-regulation of the fibroblast Shh signaling pathway members Gli $(-\square-)$ and Ptc $\left(-X_{-}\right)$in association with down-regulation of Shh $(-\triangle-)$ in type II cells, and up-regulation of type II cell SP-B $\left(-\diamond_{-}\right)$(see graphic quantitation below representative gel). Values are means $\pm \mathrm{SD}, n=5$.

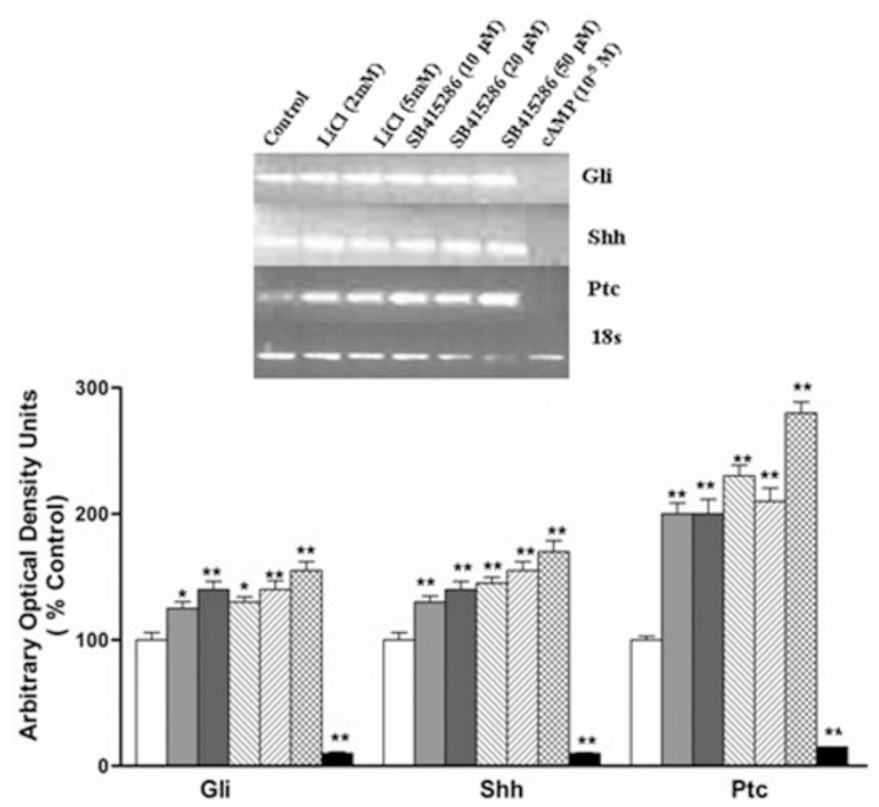

Figure 6. Dose-dependent inhibition of GSK- $3 \beta$ prevents down-regulation of the Wnt pathway. Treatment of d 5 (equal to e19) explants with either $\mathrm{LiCl}$ $(2 \mathrm{mM}=$ light gray, $5 \mathrm{mM}=$ dark gray) or the specific GSK- $3 \beta$ inhibitor $\mathrm{SB} 415286(10 \mu \mathrm{M}=$ cross hatched right to left, $20 \mu \mathrm{M}=$ cross hatched left to right, $50 \mu \mathrm{M}=$ cross hatched) prevents the spontaneous decrease in expression of Gli, Shh, and Ptc, whereas cAMP $\left(1 \times 10^{-5} \mathrm{M}=\right.$ black $)$ completely inhibited the expression of these Shh pathway-regulatory genes. Each bar represents the mean $\pm \mathrm{SD}, n=5$. $* p<0.05, * * p<0.01$, control vs treated by one-way ANOVA.

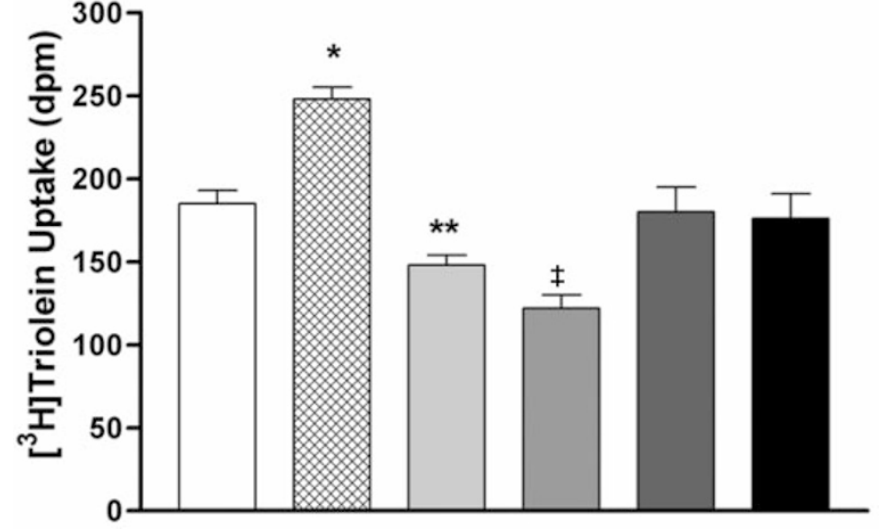

Figure 7. PKA agonists stimulate and GSK inhibitors block triglyceride uptake through a functionally common pathway. Treatment of $\mathrm{d} 4$ fetal rat lung explants with the GSK- $3 \beta$ inhibitor $\mathrm{LiCl}$ decreases triglyceride uptake in a dose-dependent manner. Each bar represents the mean $\pm \mathrm{SD}, n=5$. ${ }^{*} p<$ 0.02 ; $\neq<<0.01$, control $v s \mathrm{LiCl}$ treatment, by one-way ANOVA. cAMP $(1 \times$ $10^{-5} \mathrm{M}=$ cross hatched $)$ alone significantly increases triglyceride uptake (*p $<0.001$ control vs cAMP treatment, by one-way ANOVA $)$. LiCl $(2 \mathrm{mM}=$ light gray; $5 \mathrm{mM}=$ medium gray) inhibits triglyceride uptake in a dosedependent manner, and cAMP normalizes the $\mathrm{LiCl}$ effect $(2 \mathrm{mM}=$ dark gray; $5 \mathrm{mM}=$ black $)$.

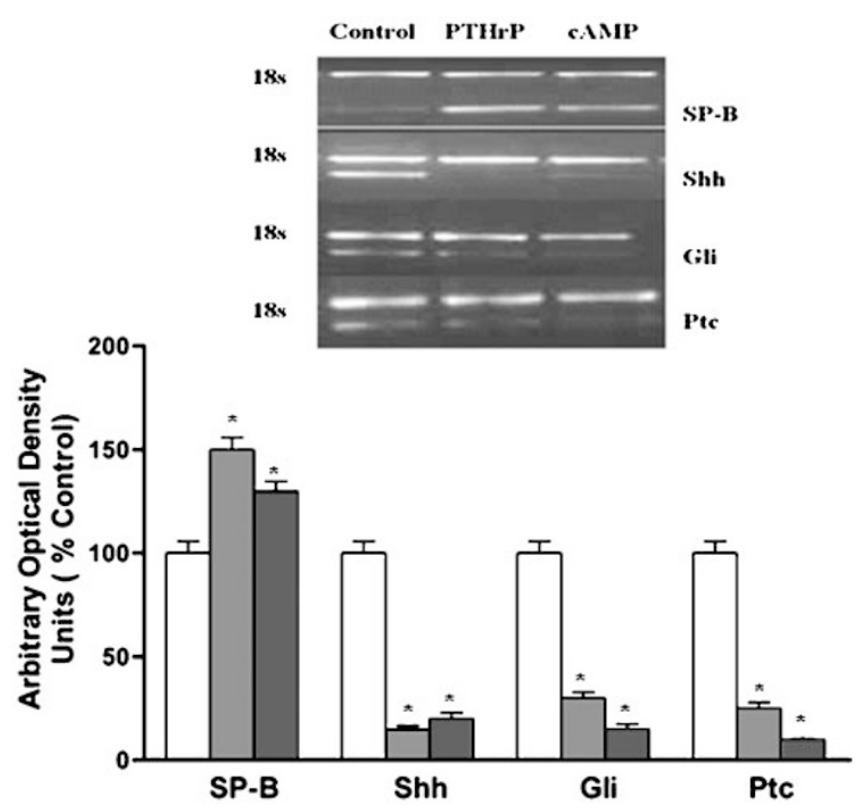

Figure 8. PKA agonists reciprocally up-regulate type II cell differentiation and down-regulate Wnt pathway expression. Day 3 (equal to e17) fetal rat lung explants were treated with PTHrP $\left(5 \times 10^{-7} \mathrm{M}=\right.$ light gray $)$ or cAMP $\left(5 \times 10^{-6} \mathrm{M}=\right.$ dark gray $)$ for $24 \mathrm{~h}$ and were subsequently analyzed for expression of SP-B, Gli, Shh, and Ptc expression by RT-PCR normalized to 18s mRNA. Note the increase in SP-B and the concomitant decreases in Gli, Shh, and Ptc. Each bar represents the mean $\pm \mathrm{SD}, n=5$ (** $^{2}<0.01$; *** $p$ $<0.001$; treated vs control, by one-way ANOVA).

regulated SP-B expression and down-regulated Shh, Gli, and Ptc. To quantitate this effect of the PKA and Wnt pathways on type II cell differentiation, we treated d 4 fetal rat lung explants with cAMP and/or $\mathrm{LiCl}$ and assayed for saturated phosphatidylcholine (satPC) synthesis (Fig. 9). cAMP itself stimulated the rate of satPC synthesis $38 \%$, whereas $\mathrm{LiCl}$ had a dose-dependent inhibitory effect on satPC synthesis, which was partially overridden by 8 -bromo-cAMP. We further ex- 


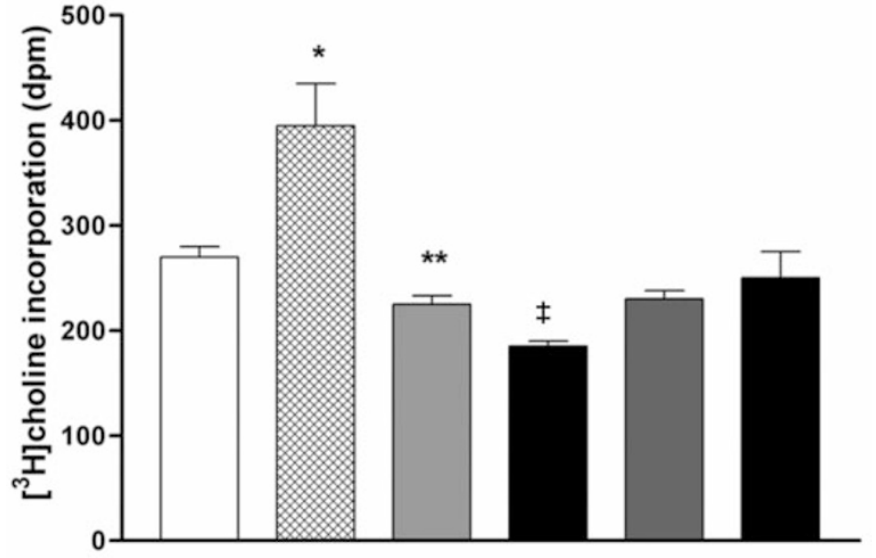

Figure 9. PKA agonists stimulate and GSK inhibitors block surfactant phospholipid synthesis through a functionally common pathway. Treatment of $\mathrm{d} 4$ fetal rat lung explants with the GSK- $3 \beta$ inhibitor LiCl decreases surfactant phospholipid synthesis in a dose-dependent manner. Each bar represents the mean $\pm \mathrm{SD}, n=5\left(* * p<0.02 ; \neq p<0.01\right.$, control $v s \mathrm{LiCl}_{2}$ treatment, by one-way ANOVA). cAMP alone (cross hatched) significantly increases surfactant phospholipid synthesis $(* p<0.001$ control $v s$ treated by one-way ANOVA). $\mathrm{LiCl}(2 \mathrm{mM}=$ light gray; $5 \mathrm{mM}=$ black $)$ inhibits triglyceride uptake in a dose-dependent manner, and cAMP normalizes the $\mathrm{LiCl}$ effect $(2 \mathrm{mM}=$ dark gray; $5 \mathrm{mM}=$ black, far right $)$, suggesting that the cAMP and $\mathrm{LiCl}$ act on type II cell differentiation through a common mechanism.

plored the interrelationship between the PKA and Wnt pathways (Fig. 10) by treating $\mathrm{d} 4$ fetal rat lung explants with a specific PKA antagonist (Rp-cAMP, $\left.1 \times 10^{-8} \mathrm{M}\right)$, PTHrP (5 $\left.\times 10^{-7} \mathrm{M}\right)$, 8-bromo-cAMP $\left(5 \times 10^{-5} \mathrm{M}\right)$, or the GSK-3 $\beta$ inhibitory Wnt pathway agonist SB415286 $\left(1 \times 10^{-8} \mathrm{M}\right)$. After $24 \mathrm{~h}$ in culture, the PKA antagonist inhibited satPC synthesis by $25 \%$, whereas both PTHrP and cAMP stimulated satPC synthesis by $50 \%$. The Wnt agonist inhibited satPC by $42 \%$. There was a $30 \%$ automaturational increase in satPC

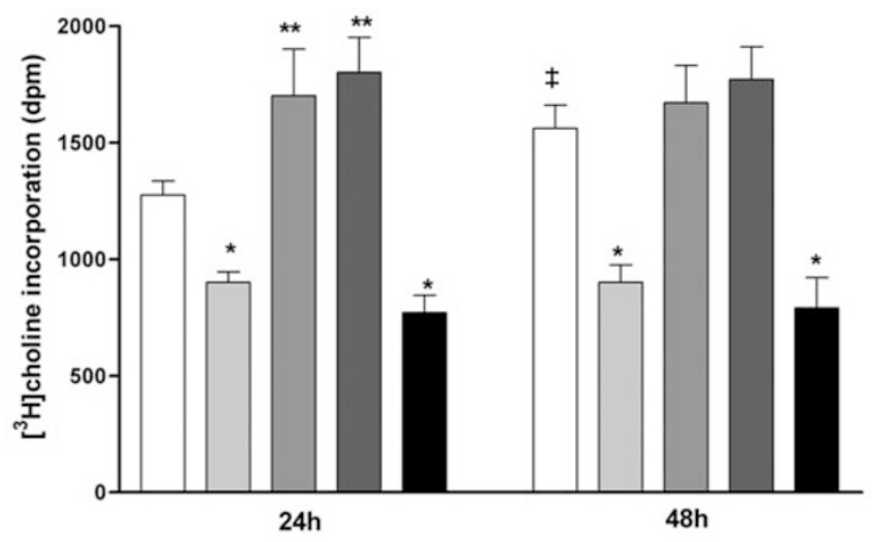

Figure 10. Inhibition of the PKA pathway inhibits surfactant phospholipid synthesis; inhibition of the Wnt Pathway stimulates surfactant phospholipid synthesis. There was a $30 \%$ automaturational increase in surfactant phospholipid synthesis at $48 \mathrm{~h}(\ddagger p<0.05,24 \mathrm{~h}$ control $v s 48 \mathrm{~h}$ control $=$ open bars $)$. Treatment of d 19 fetal rat lung explants with either a PKA antagonist (Rp-cAMP, $10^{-8} \mathrm{M}=$ light gray) or a GSK inhibitor (SB415286, $10^{-8} \mathrm{M}=$ black) inhibited surfactant phospholipid synthesis at both 24 and $48 \mathrm{~h}$. Each bar represents the mean $\pm \mathrm{SD}, n=5(* p<0.01$, control $v s$ treated, by one-way ANOVA), whereas PTHrP (medium gray) and cAMP (dark gray) stimulated it (**p $<0.01$, control $v s$ treated by one-way ANOVA), consistent with the downstream effect of fibroblast differentiation on type II cell differentiation. synthesis between 24 and $48 \mathrm{~h}$ in culture, which was inhibited $40 \%$ by the PKA antagonist. At this stage of automaturation, PTHrP and cAMP were unable to further stimulate satPC synthesis; the Wnt pathway agonist blocked the automaturational increase in satPC synthesis.

\section{DISCUSSION}

The present series of studies was designed to determine the functional interrelationship between the up-regulation of PTHrP expression by type II cells in response to fluid distension, its sequential up-regulation of fibroblast cAMPdependent PKA through its interaction with the PTHrP receptor, and the concomitant down-regulation of the $\mathrm{Wnt} / \beta$ catenin GRN. We had previously shown that PTHrP stimulates cAMP expression by the fetal rat lung fibroblast (18) and surfactant synthesis by type II cells $(2-4,9,15,20,21)$, but the intermediate steps in the pathway that coordinated these mesenchymal and epithelial effects were not determined, though we had provided experimental evidence that it was paracrine in nature (18). We subsequently showed that PTHrP up-regulated the expression of leptin by the immature lung fibroblast, and that leptin bound to its receptor on the epithelial type II cell, stimulating epithelial cell surfactant phospholipid synthesis (2) and surfactant protein expression (4), thus resolving the paracrine mechanism for PTHrP-stimulated lung maturation. However, we wanted to determine whether this mechanism could be observed in intact lung tissue, solely under the influence of alveolar fluid distension. McCray et al. (25) had previously shown that fetal rat lung explants secrete lung liquid within the developing alveoli, offering a model to study the functional interrelationship between alveolar fluid stretch, up-regulation of PTHrP expression by type II cells, and stimulation of its paracrine targets. Because PKA downregulates the fibroblast $\mathrm{Wnt} / \beta$ catenin pathway by inhibiting Gli (28), which is the only Gli family member that is Shh regulated (29), we hypothesized that PTHrP signaling is necessary for the down-regulation of the Wnt/ $\beta$ catenin GRN and up-regulation of the PKA GRN for the maturation of the lipofibroblast (30), and indirectly for the maturation of the epithelial type II cell by means of this paracrine loop (2).

The present series of experiments supports this sequence of cell-mediated endodermal-mesodermal interactions, which would account for the well-documented fluid stretchregulation of the epithelial and mesenchymal components of the alveolar interstitium during fetal lung development $(31,32)$. We used specific agonists and antagonists for the Wnt/ßcatenin and PTHrP signaling pathways to test this hypothesis, and targeted cell-type specific genes in each pathway that we had observed empirically increasing or decreasing during the spontaneous maturation of the lung explants. Although there is evidence for cAMP stimulation of type II cell surfactant synthesis, we chose a stage in lung development when cAMP would not have had such an effect, i.e. cAMP stimulates surfactant synthesis (33) but does not do so directly on immature type II cells (34). Similarly, Wnt/ $\beta$ catenin signaling is observed in both the mesoderm and endoderm of the developing lung, but the endodermal expression occurs at a 
much earlier stage of lung development (1) and would not be affected by Wnt/ $\beta$ catenin pathway agonists at e18-19, as in the present experiments. Regarding the potential toxic effects of the cell-type and pathway-specific antagonists we used, we selectively monitored the stimulation of paracrine-dependent differentiation markers in the complementary tissue compartment, e.g. monitoring endodermal markers when mesodermal cells were inhibited, and vice versa, to ensure viability of the epithelial-mesenchymal system.

Immature mesodermal cells are dominated by the Wnt/ $\beta$ catenin pathway (35), which confers the myogenic fibroblast phenotype. The developing epithelium expresses Shh, which stimulates mesodermal Wnt/ $\beta$ catenin through its receptormediated down-stream interactions with Ptc and Gli (35), actively promoting the myogenic fibroblast phenotype. Descriptively, as the endoderm and mesoderm of the alveolar interstitium mature, endodermal Shh signaling through the mesodermal Wnt/ $\beta$ catenin pathway decreases as endodermal PTHrP signaling to the mesodermal PTHrP receptor signaling pathway is concomitantly up-regulated (36). We have exploited the stretch-regulation of PTHrP $(2,3)$ to test the hypothesis that fetal lung fluid stretches the alveolar interstitium and stimulates PTHrP signaling, which down-regulates the mesodermal Wnt/ $\beta$ catenin pathway through cAMP-dependent PKA inhibition of Gli (28), up-regulating the PTHrP signaling pathway, inducing the lipofibroblast phenotype (30,37). The mature lipofibroblast produces leptin (4), which induces endodermal type II cell differentiation. The down-regulation of endodermal Shh expression by the mature epithelial type II cells ensures constitutive down-regulation of the Shh/Wnt/ $\beta$ catenin GRN, molecularly stabilizing these key alveolar interstitial phenotypes.

In support of a functional genomic interrelationship between the Wnt/ $\beta$ catenin and PTHrP GRN during lung development, Bellusci et al. (1) have shown that overexpression of Shh by type II cells causes a stage-specific delay in mesenchymal and epithelial development beginning at e16.5 in the mouse, characterized by increased mesodermal Ptc expression, at the stage in lung development when PTHrP signaling is up-regulated (38). Importantly, the PTHrP knockout mouse lung exhibits the same epithelial and mesodermal developmental characteristics as does Shh overexpression (1), and in both cases the resulting lung immaturity leads to a respiratory death at the time of birth. The same stage-specific effects of PTHrP deficiency causing failed lung development in both of these models is striking and may reflect the necessity for up-regulating PTHrP signaling to down-regulate the Wnt/ $\beta$ catenin pathway.

A wide variety of lung cell types emerge from epithelialmesenchymal interactions mediated by specific soluble paracrine growth factors and their cognate receptors residing on neighboring cells of different germ line origins (39). A variety of experiments have demonstrated that the distension of the alveolus determines its cytoarchitecture $(2,3,31,32)$. Conversely, chronic lung disease is characterized by simplification and/or loss of alveoli, which may reflect the failure of the mechanotransduction-induced mechanism of lung development described herein (20). We had previously postulated that lung development and remodeling represent a mechanistic continuum, based upon experimental observations consistent with this working hypothesis (40). The present experiments provide an integrated, cell/molecular mechanism that can generate either homeostasis or disease, depending upon the dominant cellular cross-talk.

This series of experiments has shown that alveolar fluid distension acts as an organizing principle to up-regulate the PTHrP GRN and actively down-regulate the Shh/Wnt/ $\beta$ catenin pathway in a cell-specific, spatiotemporal pattern.

\section{REFERENCES}

1. Bellusci S, Furuta Y, Rush MG, Henderson R, Winnier G, Hogan BL 1997 Involvement of Sonic hedgehog (Shh) in mouse embryonic lung growth and morphogenesis. Development 124:53-63

2. Torday JS, Rehan VK 2002 Stretch-stimulated surfactant synthesis is coordinated by the paracrine actions of PTHrP and leptin. Am J Physiol Lung Cell Mol Physiol 283:L130-L135

3. Torday JS, Sanchez-Esteban J, Rubin LP 1998 Paracrine mediators of mechanotransduction in lung development. Am J Med Sci 316:205-208

4. Torday JS, Sun H, Wang L, Torres E, Sunday ME, Rubin LP 2002 Leptin mediates the parathyroid hormone-related protein paracrine stimulation of fetal lung maturation. Am J Physiol Lung Cell Mol Physiol 282:L405-L410

5. Warburton D, Schwarz M, Tefft D, Flores-Delgado G, Anderson KD, Cardoso WV 2000 The molecular basis of lung morphogenesis. Mech Dev 92:55-81

6. Umek RM, Friedman AD, McKnight SL 1991 CCAAT-enhancer binding protein: a component of a differentiation switch. Science 251:288-292

7. Brody JS, Williams MC 1992 Pulmonary alveolar epithelial cell differentiation. Annu Rev Physiol 54:351-371

8. Boitano S, Isakson BE, Lubman RL 2002 Culturing alveolar type I, alveolar type II, and mixed cell populations by altering the extracellular matrix promotes changes in intercellular signaling mechanisms. Chest 121:35S-36S

9. Torday JS, Rehan VK 2003 Mechanotransduction determines the structure and function of lung and bone: a theoretical model for the pathophysiology of chronic disease. Cell Biochem Biophys 37:235-246

10. Ballard PL, Gonzales LW, Williams MC, Roberts JM, Jacobs MM 1991 Differentiation of type II cells during explant culture of human fetal lung is accelerated by endogenous prostanoids and adenosine $3^{\prime}, 5^{\prime}$-monophosphate. Endocrinology 128:2916-2924

11. Mendelson CR 2000 Endocrinology of the Lung: Development and Surfactant Synthesis. Humana Press, Totowa, NJ, pp 1-336

12. Boros LG, Torday JS, Paul Lee WN, Rehan VK 2002 Oxygen-induced metabolic changes and transdifferentiation in immature fetal rat lung lipofibroblasts. Mol Genet Metab 77:230-236

13. Hastings RH, Ryan RM, D'Angio CT, Holm BA, Patel A, Quintana R, Biederman E, Burton DW, Deftos LJ 2002 Parathyroid hormone-related protein response to hyperoxic lung injury. Am J Physiol Lung Cell Mol Physiol 282:L1198-L1208

14. Torday J, Hua J, Slavin R 1995 Metabolism and fate of neutral lipids of fetal lung fibroblast origin. Biochim Biophys Acta 1254:198-206

15. Rehan V, Torday J 2003 Hyperoxia augments pulmonary lipofibroblast-tomyofibroblast transdifferentiation. Cell Biochem Biophys 38:239-250

16. Moss TJ, Nitsos I, Kramer BW, Ikegami M, Newnham JP, Jobe AH 2002 Intraamniotic endotoxin induces lung maturation by direct effects on the developing respiratory tract in preterm sheep. Am J Obstet Gynecol 187:1059-1065

17. Rubin LP, Kovacs CS, De Paepe ME, Tsai SW, Torday JS, Kronenberg HM 2004 Arrested pulmonary alveolar cytodifferentiation and defective surfactant synthesis in mice missing the gene for parathyroid hormone-related protein. Dev Dyn 230:278289

18. Rubin LP, Kifor O, Hua J, Brown EM, Torday JS 1994 Parathyroid hormone (PTH) and PTH-related protein stimulate surfactant phospholipid synthesis in rat fetal lung, apparently by a mesenchymal-epithelial mechanism. Biochim Biophys Acta 1223:91-100

19. Speziale MV, Mannino FL, Hastings RH, Deftos LJ 1998 Parathyroid hormonerelated protein in tracheal aspirates of newborn infants. Pediatr Res 43:660-665

20. Torday JS, Torres E, Rehan VK 2003 The role of fibroblast transdifferentiation in lung epithelial cell proliferation, differentiation, and repair in vitro. Pediatr Pathol Mol Med 22:189-207

21. Rehan VK, Wang Y, Sugano S, Romero S, Chen X, Santos J, Khazanchi A, Torday JS 2005 Mechanism of nicotine-induced pulmonary fibroblast transdifferentiation. Am J Physiol Lung Cell Mol Physiol 289:L667-L676

22. Bostrom H, Willetts K, Pekny M, Leveen P, Lindahl P, Hedstrand H, Pekna M, Hellstrom M, Gebre-Medhin S, Schalling M, Nilsson M, Kurland S, Tornell J, Heath JK, Betsholtz C 1996 PDGF-A signaling is a critical event in lung alveolar myofibroblast development and alveogenesis. Cell 85:863-873

23. Low RB 1999 Modulation of myofibroblast and smooth-muscle phenotypes in the lung. Curr Top Pathol 93:19-26

24. Kapur P, Holm BA, Irish MS, Patel A, Glick PL 1999 Tracheal ligation and mechanical ventilation do not improve the antioxidant enzyme status in the lamb model of congenital diaphragmatic hernia. J Pediatr Surg 34:270-272 
25. McCray PB Jr., Bettencourt JD, Bastacky J 1992 Secretion of lung fluid by the developing fetal rat alveolar epithelium in organ culture. Am J Respir Cell Mol Biol 6:609-616

26. Gross I, Smith GJ, Maniscalco WM, Czajka MR, Wilson CM, Rooney SA 1978 An organ culture model for study of biochemical development of fetal rat lung. J Appl Physiol 45:355-362

27. Torday JS 1990 Androgens delay human fetal lung maturation in vitro. Endocrinology 126:3240-3244

28. Kaesler S, Luscher B, Ruther U 2000 Transcriptional activity of GLI1 is negatively regulated by protein kinase A. Biol Chem 381:545-551

29. Walterhouse DO, Lamm ML, Villavicencio E, Iannaccone PM 2003 Emerging roles for hedgehog-patched-Gli signal transduction in reproduction. Biol Reprod 69:8-14

30. McGowan SE, Torday JS 1997 The pulmonary lipofibroblast (lipid interstitial cell) and its contributions to alveolar development. Annu Rev Physiol 59:43-62

31. Alcorn D, Adamson TM, Lambert TF, Maloney JE, Ritchie BC, Robinson PM 1977 Morphological effects of chronic tracheal ligation and drainage in the fetal lamb lung. J Anat 123:649-660

32. Moessinger AC, Harding R, Adamson TM, Singh M, Kiu GT 1990 Role of lung fluid volume in growth and maturation of the fetal sheep lung. J Clin Invest 86:1270-1277

33. Aeberhard EE, Scott ML, Barrett CT, Kaplan SA 1984 Effects of cyclic AMP analogues and phosphodiesterase inhibitors on phospholipid biosynthesis in fetal type II pneumocytes. Biochim Biophys Acta 803:29-38
34. Mendelson CR, Acarregui MJ, Odom MJ, Boggaram V 1991 Developmental and hormonal regulation of surfactant protein A (SP-A) gene expression in fetal lung. J Dev Physiol 15:61-69

35. Huelsken J, Birchmeier W 2001 New aspects of Wnt signaling pathways in higher vertebrates. Curr Opin Genet Dev 11:547-553

36. Karperien M, van Dijk TB, Hoeijmakers T, Cremers F, Abou-Samra AB, Boonstra J, de Laat SW, Defize LH 1994 Expression pattern of parathyroid hormone/ parathyroid hormone related peptide receptor mRNA in mouse postimplantation embryos indicates involvement in multiple developmental processes. Mech Dev 47:29-42

37. Schultz CJ, Torres E, Londos C, Torday JS 2002 Role of adipocyte differentiationrelated protein in surfactant phospholipids synthesis by type II cells. Am J Physiol Lung Cell Mol Physiol 283:L288-L296

38. Burton PB, Moniz C, Quirke P, Malik A, Bui TD, Juppner H, Segre GV, Knight DE 1992 Parathyroid hormone-related peptide: expression in fetal and neonatal development. J Pathol 167:291-296

39. Shannon JM, Hyatt BA 2004 Epithelial-mesenchymal interactions in the developing lung. Annu Rev Physiol 66:625-645

40. Demayo F, Minoo P, Plopper CG, Schuger L, Shannon J, Torday JS 2002 Mesenchymal-epithelial interactions in lung development and repair: are modeling and remodeling the same process? Am J Physiol Lung Cell Mol Physiol 283:L510 L517 